\title{
Glastonbury Holy Thorn
}

Much more than the 'biography of a symbol'

DOI: https://doi.org/10.30664/ar.102230

(c)(Attribution 4.0 International (CC BY 4.0)

Adam Stout, Glastonbury Holy Thorn:

Story of a Legend (Glastonbury: Green \&

Pleasant Publishing, 2020), 156 pp.

Many people believe that Glastonbury - a town of about 9,000 inhabitants situated in the south-west of England - is the most powerful place on Earth. Glastonbury is arguably characterised by an utter unworldliness and it has often been described as a place where 'the veil is very thin'. It is thought of as the legendary Isle of Avalon where King Arthur is said to be buried. Some argue that Glastonbury was venerated as a sacred place in Britain before Christianity and was the site of the first Christian community, reputedly founded by Joseph of Arimathea. Today Glastonbury can be seen as one of the most popular and multivalent pilgrimage sites in the UK and as such it has attracted considerable vernacular as well as academic research. Dr Marion Bowman has suggested that Glastonbury is not one place but many; it is a place of parallel pasts and presents. This observation also becomes evident in the book under review here; Glastonbury Holy Thorn: Story of a Legend, by the historian and writer Dr Adam Stout. He has written and lectured widely on several Glastonbury-related topics, and he is a popular speaker at aca-

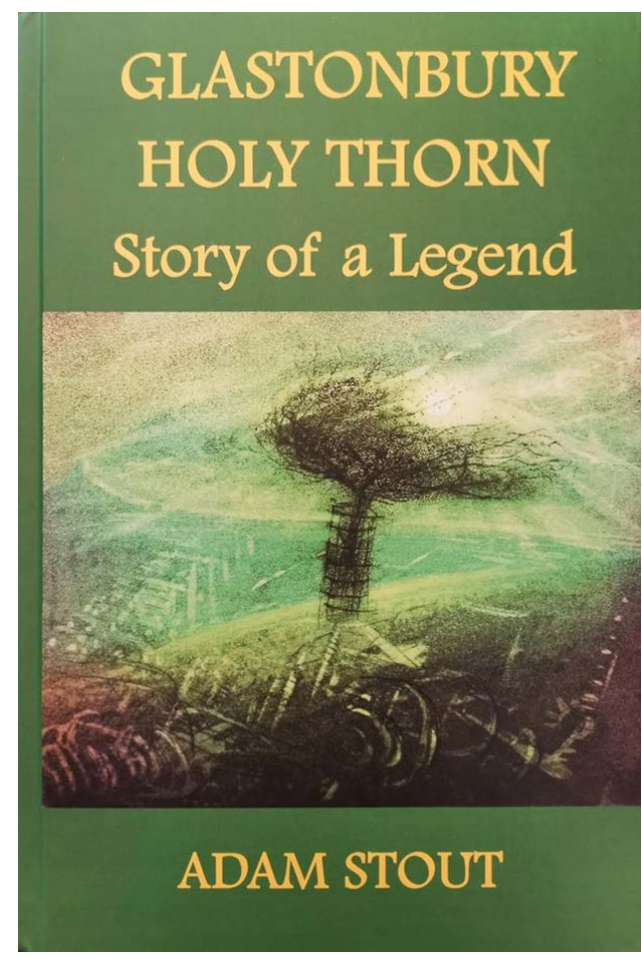

demic conferences as well as more informal gatherings. By presenting and reflecting on a myriad of beliefs and stories associated with the Thorn, from the earliest record of it to the present day, in his new book Stout is effectively concerned with the anatomy of a legend. And much more.

The Glastonbury Holy Thorn - a tree that famously blossoms twice a year, at Christmas and in spring - is one of the 
symbols of Glastonbury, alongside the Tor and Glastonbury Abbey. According to legend, Joseph of Arimathea visited Glastonbury and thrust his staff into Wirrall Hill (also known as Wearyall Hill), which then miraculously grew into the Holy Thorn. When I first went on a field trip to Glastonbury, in 2011, it was unfortunately too late to see the tree standing on Wirrall Hill in blossom. All that was left, after a brutal attack which had taken place a year earlier, was a stump of the tree that had meant so much to people from different spiritual backgrounds. Adam Stout offers a poignant description of its destruction and people's responses to it, drawing parallels with the year 1647 when the tree had been chopped down by Puritan soldiers on the basis of it being a 'superstition'. One of the unexpected effects of the 2010 desecration was that it brought some Christians and Pagans closer together in their sorrow (pp. 113-14).

Glastonbury enthusiasts have been waiting for a long time for Stout's latest book. I remember reading its predecessor, The Thorn and the Waters: Miraculous Glastonbury in the Eighteenth Century by Adam Stout (published in 2007), and feeling sorry that the book was dedicated to only one century in the history of Glastonbury. This new academic book by Adam Stout tells the history of Glastonbury - and England - through the story of the Holy Thorn. This time Stout takes the reader on a journey through the centuries, tracing legends associated with the Thorn, and exploring how these legends were born and changed over time. The Glastonbury Holy Thorn has been extremely vulnerable at certain times in history; it has often been used as a metaphorical weapon. For example, some Protestants - including Queen Elizabeth - claimed that as the Thorn had grown from Joseph of Arimathea's staff it proved that Christianity arrived in Britain centuries before Pope Gregory sent St Augustine to England in the late sixth century. At the same time, the Thorn was a 'very Catholic miracle, and one whose continued existence bolstered believers and troubled their tormentors' (p. 24). Furthermore, some people considered the Thorn to be a useful link to the pre-Christian world - the story about the staff that became a tree fit nicely with the belief that the pre-Christian Pagans of Britain had been tree-worshipping Druids (p. 94).

The book abounds with exciting facts about England's kings and queens as well as ordinary folk. For example, Stout explores why the Glastonbury Thorn won royal approval, and became England's licensed miracle in the reign of James I (p. 27) and reflects on the fluctuating tradition of sending the reigning monarch a flowering sprig of the Holy Thorn for Christmas. He also provides a fascinating account of a pilgrimage taken in 1755 by seventy-one-year-old John Jackson, who was concerned about the new calendar (the Calendar Act passed in 1751 brought Britain into line with the Gregorian calendar used in the rest of Europe, and among other things led to the rescheduling of Christmas). Stout writes: 'And suddenly the Christmas-flowering properties of the Glastonbury Thorn acquired a whole new significance. Would the holy plant observe the new regime, or would it defy Parliament and continue to blossom on the old day? Never was plant so closely monitored as the Thorn that Christmas of $1752 / 3$, and both sides in the debate knew well what was at stake' (p. 62). John Jackson set out on his 185-mile-journey from his home in Yorkshire on All Saints Day, and 'trudged for weeks through the mire and foul weather of an English winter, and after many wayfaring adventures arrived in Glastonbury to witness the Thorn work its 
magic on Old Christmas'. Jackson's pilgrimage was not only motivated by his 'wish to prove the Thorn's calendrical habits', it was also a quest for old-fashioned Christian values (pp. 66-7).

The author is to be commended for the diverse methodology used in his research. Alongside sources one would expect a historian to use (archives and other written sources, academic literature), Stout has conducted interviews with various people, for example, Morgana West from the Glastonbury Pilgrim Reception Centre, as well as other local people. He also conducted a straw poll on a local Facebook page. Thanks to this wide range of sources the book feels rounded and well balanced. The balance has also been struck in the style of the book - Stout is not only a meticulous researcher but also a good storyteller with a pleasant, dry sense of humour.

With regard to the structure of the book, splitting chapters into shorter - aptly and often humorously entitled - subsections makes reading it a pleasure. The book contains some carefully selected illustrations - line drawings, photographs, and colour plates.

To sum up, in the book's blurb it is written:

The Holy Thorn of Glastonbury is the stuff that legends are made of. Stories grow on it like fruit and wrap around it like creepers. It's a shape-shifter. It's been Catholic, Protestant, Pagan, universal. It's succoured royalty, loyalty, defiance and subversion. It's been condemned as patriarchal and revered as a feminine spirit. It's been harnessed by imperialists and peacemakers and nationalists and universalists. It's stood for better times and better days. For Christmas cheer and better nature, for all trees and all nature, for peace and for hope. This book is the biography of a symbol.

This is a beautiful and poetic summary. If anything, I would argue that it is perhaps a little too limiting and doesn't do the book the justice it deserves (the same goes for the somewhat vague subtitle of the book: Story of a Legend). Even though the book is dedicated to the history and legends about the Glastonbury Holy Thorn, you don't actually need to have any particular or prior interest in the Holy Thorn, or indeed even in Glastonbury, in order to enjoy the book. Adam Stout calls his work the Straight History of Weird' (p. 3). Therefore, anyone who is interested in the (especially magical, esoteric) history of England will enjoy reading it and will no doubt fill in some of the gaps in their knowledge about this extraordinary and truly fascinating island.

Tiina Sepp

Tiina Sepp is Research Fellow at the Department of Estonian and Comparative Folklore, University of Tartu, Estonia. 